\title{
Practice and Exploration of Module Project Teaching Method of "Architectural Design Foundation"
}

\author{
Qionglin Liu \\ School of Art and Design \\ Guangdong University of Finance and Economics \\ Guangzhou, China
}

\author{
Jun Chen \\ Guangzhou Zhuding Building and Planning and Design \\ Institute Co., Ltd. \\ Guangzhou, China 510641
}

\begin{abstract}
Under the vision and action of China's construction of the Silk Road Economic Belt and the 21st Century Maritime Silk Road, the globalization of art education is unstoppable. The basic courses of environmental design majors in art schools are advancing with the times. It can not only meet the needs of regional economy, social development and the strategy of cultural power construction, but also maintain the characteristics of talent cultivation in the background of art colleges and universities. This paper attempts to take the "Architectural Design Foundation" as an example, and integrates the curriculum connotation of "skills learning" and "cultivation and shaping". The basic module and the expansion module are integrated into practical projects as a modular project teaching method to build a professional high-level innovative applied talent training curriculum system suitable environment design. It is to promote the cultivation of Chinese cultural and artistic talents.
\end{abstract}

Keywords—environmental design major; architectural design basis; module project teaching method; integration; innovation

\section{INTRODUCTION}

In 2012, the country established design science as a firstlevel discipline. The design education adapting to the development and transformation of modern society has always been accompanied by the development of disciplines. In 2014, promoting the integration of cultural creativity and related industries is put forward in "several opinions of the state council on promoting the integration of cultural creativity and design services with related industries". In 2018, the State promulgated the National Education Quality Assurance System Standards (including the art)--"National Standards for Undergraduate Professional Teaching Quality". At present, under the vision and action of China's construction of the Silk Road Economic Belt and the 21st Century Maritime Silk Road, the globalization of art education is unstoppable. As an environmental design major of art colleges and universities, how can the basic curriculum keep pace with the times? How to cultivate the talent that meet the needs of regional economic, social development and cultural country construction strategies, and maintain the talent cultivation characteristic under academic background of the university?

China's environmental art discipline began in 1985. And it is a new and comprehensive developmental profession that is urgently needed in modern society. ${ }^{1}$ The environmental design is based on the architecture in the environment, and comprehensively to use artistic methods and engineering techniques in its internal and external space, and to implement the design of micro-environment such as urban and rural landscape, landscape architecture and architectural interior. ${ }^{2}$ At the same time, environmental design is also the interior and exterior space design of the building. It is inseparable from the relationship between architecture and art. It is standing within the scope of the Academy of Fine Arts or the School of Art and Design. "Preliminary of architecture design" is one of the basic courses of the environmental design profession (Architectural and Environmental Design), which often draws on the similar traditional basic curriculum system of the architectural profession of the engineering colleges with a long history or the similar subject curriculum system of the Academy of Fine Arts.

The teaching system of the traditional Chinese architecture foundation course is based on the Beaux-Arts system in Paris and the University of Pennsylvania. It is a part of the teaching system based on the type of building after the founding of New China. ${ }^{3}$ At this stage, the two major directions of "skills learning" and "cultivation shaping" have been formed. The curriculum settings combine three concepts: basic concepts, architectural skills and basic accomplishments, while emphasizing the interaction between teaching and learning, including handto-brain interaction and interaction within and outside the classroom.

Compared with the quality of the students of the School of Architecture, the students of art colleges have a good foundation of art, while they know little about the theory of environmental design and related engineering techniques. At the same time, the environmental design majors of the Art

Zhai Xiaonan. Reform of Practical Teaching of Environmenta Art Design Major in Colleges and Universities[J]. Shenyang: Journal of Shenyang University (Social Science Edition). 2010.12(4):89-91.

Research Group of Design Discipline of Chinese Colleges and Universities, Design Course of Chinese Higher Education [D]. Beijing: Tsinghua University Press, 2015

Wu Zhihong, Gao Lei, Order, Media and Expression. Research on the preliminary teaching of architecture combined with buzza and modern system[J]. Beijing: China Architecture Education, 2015, 03. P56. 
College and the architecture majors in engineering colleges differ in terms of teachers, students, and equipment. Combining with the characteristics of students in art colleges, to learn from the excellent "Architectural Design Foundation" course of engineering school, to construct a teaching system of "Architectural Design Foundation" course suitable for application talents training of environmental design of art colleges to meet the needs of talent training in the transformation of modern society has always been the subject of exploration by faculty members.

The Department of Environmental Design under the School of Art and Design of Guangdong University of Finance and Economics start from the space design teaching and research section in 2008. In 2012, it was formally established as the "Environmental Design Department". Since 2014, the teachers of the department have continued to explore the teaching reform of the "Architectural Design Foundation" course. After three years of practice, this course has changed from the original "single orientation" to "multiple guidance", from "professional knowledge" to "professional integration". At the same time, the comprehensive quality of students' engineering drawing technology ability and artistic innovation ability has been greatly improved.

\section{THE RECONSTRUCTION OF CURRICULUM TEACHING CONCEPT}

The undergraduate training of architecture majors in engineering colleges has gradually shifted from focusing on "production" architects to "design" architects. ${ }^{4}$ For example, the School of Architecture of South China University of Technology offers art (drawing) courses. Tongji University offers city and architecture surveys. The environmental design majors of Zhejiang University takes Chinese classical gardens as a native language. In the initial stage of the subject education, the student experience values and social responsibilities are established, and the students' works are increasingly taking the initiative to absorb the nutrients of various art categories.

Taking "Architectural Design Foundation" as an example, the courses of engineering colleges emphasize the basic knowledge of building and performance training, and the courses of art colleges emphasize professional techniques. According to the development orientation and school running-school concept, the environmental design department of the art school with business background put forward the teaching execution plan of "Architectural Design Foundation" ${ }^{5}$, which comprehensively cultivates building basic theory knowledge, basic design method and environmental design value. It is to cultivate students' good

Wu Nong, Wang Haozhe. Looking at the Problems in China's Higher Architecture Education from the Pritzker Architecture PrizeTaking the Teaching Content of Architectural Design as an Example[J]. Chongqing: Higher Architecture Education, Vol. 24, No. 5, 2015. P5-8.

The philosophy of running a school in Guangdong University of Finance and Economics is "to study rites and music, and be good at the profession". The characteristics of running a school are "integration of commerce and law, practice entrepreneurship, and multi-disciplinary cooperation". learning habits, self-learning ability, expression ability and teamwork ability.

Based on the experience and summary of several years of teaching practice, we find that the following four core issues are addressed in the teaching of "Architectural Design Foundation":

First, how to stimulate students' interest and enthusiasm for design learning;

Second, how to develop students' ability to map recognition and drawing;

Third, how to make students better understand the thinking and basic methods of architectural design, master multi-dimensional design thinking and expression skills including sketches, models, modeling, illustrations, engineering drawings;

Fourth, how to integrate the basic design course with the relevant courses (such as the connection with the "Architectural Design Topics" in the upper grades).

By thinking about these four core issues, in view of the status that professional students are the art candidates for college entrance examination and the training objectives of the school's professional talents, it is proposed to give full play to the students' aesthetic advantages, while supplementing science and engineering knowledge, improving logical thinking ability and engineering drawing ability. The means of implementation is to introduce practical design projects.

\section{The Curriculum TEACHING FrameWORK DESIGN}

The teaching framework consists of four major elements: teaching thought, teaching objectives, teaching mode and teaching content. The teaching of environmental design is not based on the direction of architecture, but on the training ideas of applied talents in urban design, architectural design, interior design, display design, and landscape design (Fig. 1). Therefore, the "Architectural Design Foundation" is set in the first eight weeks of the second semester of the university, a total of 64 class hours. The colleges and universities should guide and motivate students' interest in such a limited time, and cultivate students' "skills learning" and "cultivation shaping". The teaching mode and teaching content design of the course is particularly important. In view of this, the teachers can introduce module teaching method and project-based teaching method, forming into module project teaching method. With the practice, it obtains good teaching results.

\section{A. Teaching Mode}

1) Module teaching method: The module teaching method is a teaching model developed by the ILO in the early 1970s with the on-site teaching and skill training as the core. The flexibility, pertinence, reality and economy of the teaching model are very suitable for the transition of China's education from "testing" to "quality". 


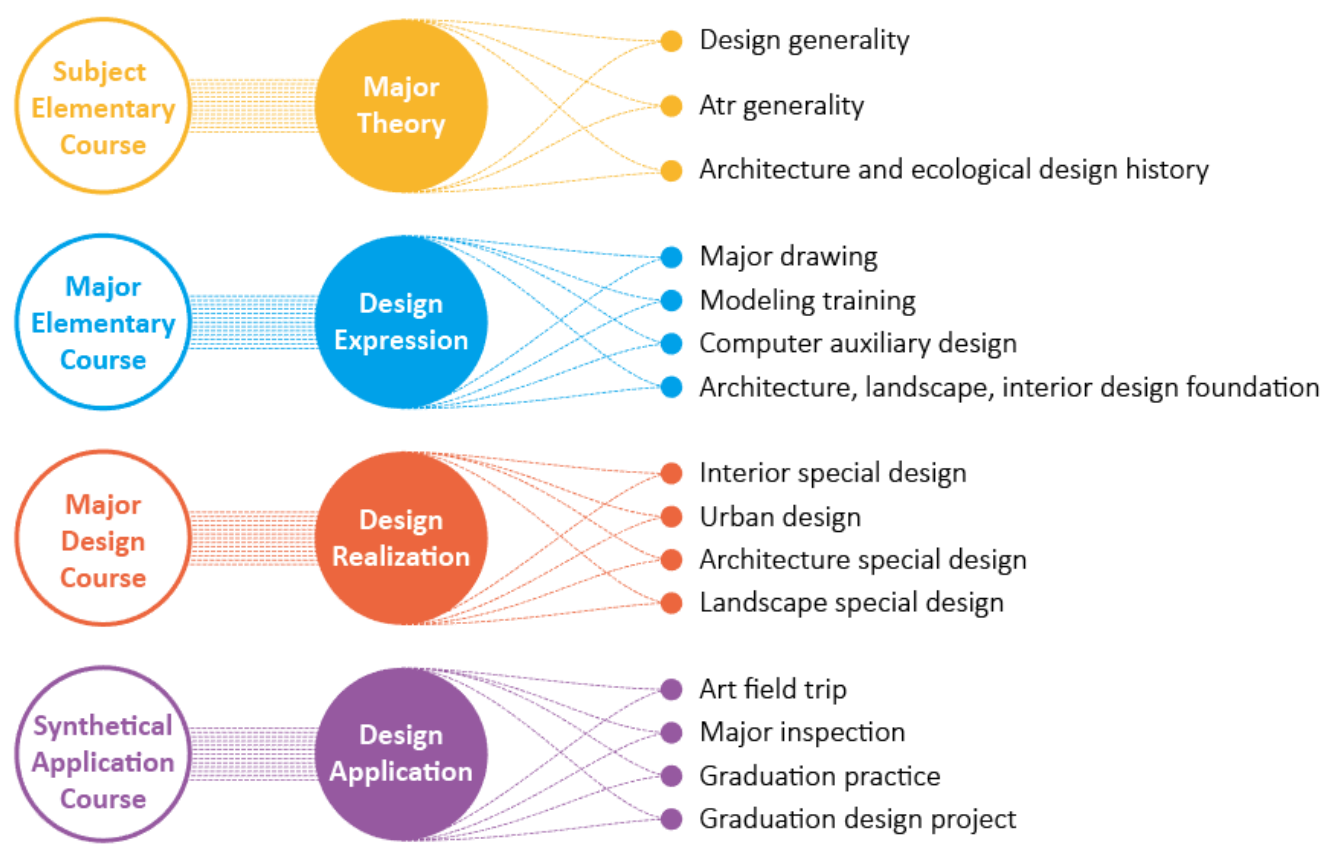

Fig. 1. Course group of environmental design professional teaching system.

In accordance with the "module teaching method", we can refer to Guo Qi's integration of four complementary modules such as "technical training", "formal composition", "space limitation" and "construction design". ${ }^{6}$ Combining with the teaching objectives, we will sort out the original tutorials, and integrate the curriculum into "architectural knowledge", "architectural literacy", "technical training", "space limitation", "thinking training" and "construction design" according to the staged training process from the surface to the centre. ${ }^{7}$ (Fig. 2)

6 The essence of "modular" teaching is to organize related knowledge in the whole teaching content into several independent modules, and carry out targeted teaching and training for these modules, and realize the control and guidance of all knowledge throughout the teaching process, forming reasonable evaluation of the results of the stage. Thus, it will promote the transparent thinking of the entire teaching process, and make the whole teaching more organized. Guo Qi. "Module" Teaching Analysis of the Initial Construction Course [J]. Beijing: Building Materials and Decoration, 2017, 09. P168

7 The "Forms Composition" course has been included in the display design course in the department. At the same time, this paper also refers to the rectification experience of "architectural design foundation" of the discipline group of basic teaching of architectural design of Tongji university, and divides the design basis, architectural introduction, architectural expression into "architectural characteristics", "artistic practice", "social cognition" and other teaching courses. It provides students with direct perceptual knowledge of space, material and structure. Wang Haisong. 3+1 Student Work Exhibition of Architecture Department and the 2nd Excellent Student work Exhibition of Architecture Departmen of Shanghai University [M]. Beijing: China Building Industry Press, 2006. P8

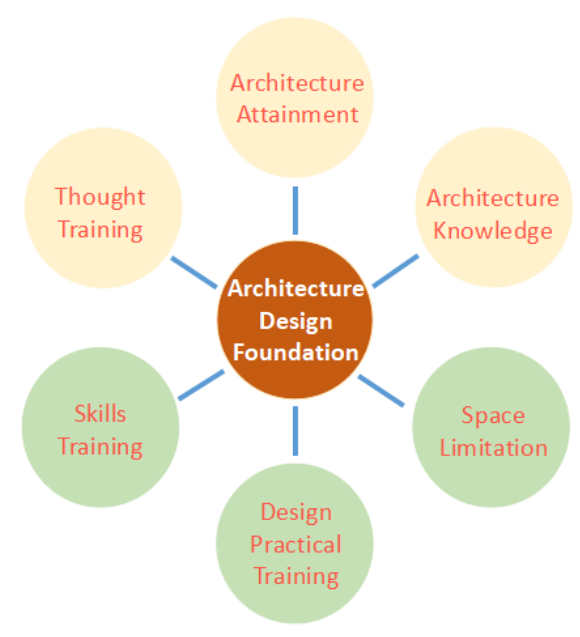

Fig. 2. Relationship between teaching modules of basic course. 
These six "module" teaching methods are based on the traditional architecture foundation and technical training, introducing the "architectural literacy" and "thinking training" mode. The teaching content and direction of the "Architectural Design Foundation" of the environmental design profession are close to the quality cultivation of students of architecture major. It emphasizes the integration of knowledge and ability in the teaching method, and the consistency of knowledge and practice, and carries out relevant theoretical knowledge, practical experience, and operational skills according to each module to achieve the training goal of talents who have application ability and professional quality.

2) Project teaching method: Project teaching method was first seen in the work-learning education in Europe in the 18th century and the cooperative education in the United States in the 19th century, aiming to cultivate practical talents for the society ${ }^{8}$. It has the ability to significantly improve students' ability to solve problems, learn to embrace new knowledge, and collaborate with others to conduct project operations ${ }^{9}$. Therefore, in the middle and late 20th century, with the continuous development of industrialization and informatization, the project teaching method has gradually become an important teaching trend.

The research on project teaching method in China started in the beginning of the 21 st century ${ }^{10}$. The project teaching method is characterized by requiring students to undertake one or two small research projects independently or in groups of individuals, conducting independent research and analysis, and presenting exchange project results in the whole class.

3) Module project teaching method: Combining the advantages of the two modes of "module + project", we set the knowledge system as the teaching content system, make the decomposition, reorganization and integration according to the capabilities of the three practical task books, transform the knowledge points into employment-oriented competency training system, promote the integration and modularization of the course content, and highlight the applicability and practicality of the course. ${ }^{11}$

Combining the theoretical part of Mr. Tian Xuezhe's "Elementary Architecture" and the construction task book of Gu Daqing/Bai Tingwei's "Introduction to Architectural Design", the three training tasks of "Architectural Design" will be set up as "Small Space: Dormitory Space Design of the Student", "Site Design: South Library Site Measurement and Transformation" and "Architectural Design: Kindergarten Architecture Design of Nine Class" according to the theory and characteristic of "project teaching method". These three projects are actual projects on campus. The dormitory unit space (small space), venue space (site space) and kindergarten building space (large space) are used as design carriers to gradually cultivate and strengthen students' design ability and practical ability (see "Table I").
8 The project pedagogy is an action-oriented professional pedagogy. It is a student-centered activity teaching method jointly created by the famous American child educator, Dr. Katz, professor of Illinois University, and Dr. Chad, a Canadian children's educator and professor of the University of Alberta.

9 The US project teaching method has been used since the elementary school. Combining teaching content, the teachers require students to undertake one or two small research projects independently or in groups of several. During the implementation of the project, students take the initiative to conduct research, consult relevant literature, collect various materials, conduct analysis and research, and finally display and exchange results in the whole class. Liu Hongmei. Application Research of Project Teaching Mode in Basic Computer Application Course of Secondary Vocational School [D]. Jinan: Shandong Normal University, 2012.

10 Since the Canadian educator Dr. Chad brought the project teaching method to China for the first time in April 2001, more and more schools and teachers have begun to pay attention to the practical application of the project teaching method.
11 Guo Jian. Practice and Exploration of Modular Project Teaching Method [D]. Shanghai: Central China Normal University, 2015. 
TABLE I. LIST OF TRAINING COURSES FOR "ARCHITECTURAL DESIGN FOUNDATION"

\begin{tabular}{|c|c|c|c|c|c|c|}
\hline No. & Project & Title & Scale & Design Project contents & Form & $\begin{array}{c}\begin{array}{c}\text { Homework } \\
\text { form }\end{array} \\
\end{array}$ \\
\hline $\begin{array}{l}\text { First } \\
\text { training task } \\
\text { description }\end{array}$ & $\begin{array}{ll}\text { Small } & \text { space } \\
\text { design } & \end{array}$ & $\begin{array}{l}\text { 《 small space; student } \\
\text { dormitory design } 》\end{array}$ & 21 square meters & $\begin{array}{l}\text { Use the school dormitory } \\
\text { space as a boundary, design a } \\
\text { dormitory space for two } \\
\text { students }\end{array}$ & \multirow[t]{3}{*}{$\begin{array}{l}3 \text { people / } \\
\text { group }\end{array}$} & \multirow{3}{*}{$\begin{array}{l}\text { 1. Drawing } \\
\text { 2. Model } \\
\text { 3. PPT } \\
\text { report } \\
\text { 4.Tweets on } \\
\text { official account }\end{array}$} \\
\hline $\begin{array}{l}\text { Second } \\
\text { training task } \\
\text { description }\end{array}$ & Site design & 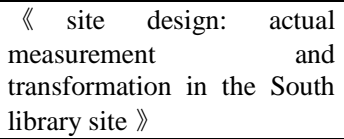 & $\begin{array}{l}500 \quad \text { square } \\
\text { meters, } \\
2 \text { floors in some } \\
\text { parts }\end{array}$ & $\begin{array}{l}\text { Use the site around the south } \\
\text { library as the boundary and } \\
\text { have actual measurement and } \\
\text { transformation design }\end{array}$ & & \\
\hline $\begin{array}{l}\text { Third } \\
\text { Training } \\
\text { task } \\
\text { description }\end{array}$ & $\begin{array}{l}\text { Architecture } \\
\text { design }\end{array}$ & $\begin{array}{ll}《 \text { architecture } & \text { design: } \\
\text { architecture } & \text { design } \\
\text { Kindergarten class } 9 》\end{array}$ & $\begin{array}{l}3000 \text { square } \\
\text { meters, } \\
3 \text { floors in some } \\
\text { parts }\end{array}$ & $\begin{array}{ll}\text { Design } & \text { class } \\
\text { Kindergarten } & \end{array}$ & & \\
\hline
\end{tabular}

\section{B. Teaching Content}

In the teaching content, Mr. Tian Xuezhe's "Elementary Architecture" is the basic content of the textbook. It introduces the contents of Pritzker Architects' deeds and works, house drawing specifications, architectural thinking, and registered architects' drawing examinations. In the process of module-based and project-based teaching, the professional knowledge and professional practice are expanded.

1) Architecture award: Among the many world architecture awards, we chose the Pritzker Architecture Prize, which is known as the Nobel Prize in architecture, for teaching plans. This award recognizes architects in the world who demonstrate their talents, imagination and social responsibility in architectural design, as well as lasting and outstanding contribution to the built environment and humanity through architectural art. ${ }^{12}$ This will help students understand contemporary architectural development, design values and master design techniques.

Mr. Wang Shu, the winner of Pritzker 2012, merged with the traditional architectural design of garden on the yangtze delta in China and passed on the excellent traditional culture of China. Mr. Bei Yuming, the winner of Pritzker 1983, integrated the concept of natural space, focused on historical roots and was good at the application of traditional design ideas. The interpretation of their thoughts and works can greatly enhance the confidence of Chinese culture, stimulate students' interest and enthusiasm for design, and strengthen the cultural subject consciousness and cultural innovation consciousness of college students. The experience and works of award-winning architects in the United States, Europe, Japan, North America, and Spain are not only instructive, but also have great benefits for college students to establish a sense of social responsibility.
2) Architectural drawing specifications: It should introduce the "Unified Standard for Building Construction Drawing" (GBT50001-2010) into the teaching content, and emphasize the standardization and rigor of architectural drawing. The size label, the north pointing needle, icon, scale, picture frame size, lines and other expressions of building surveying and plan design are standard.

3) Graphic thinking: Art students have rich perceptual thinking, lacking rigorous logical thinking and expression. They use the "Graphic Thinking--Architectural Performance Techniques" by Lasso (Qiu Xianfeng, etc. translation) as the teaching content, and use the graphic skills of architects to assist architectural design thinking. At the same time, we can use the analytical performance of the winning entries of the architectural competition to interpret and analyze logical thinking and expressions. It is helpful to cultivate the logical thinking analysis ability and creativity of environmental design students.

\section{THE INTEGRATION OF CURRICULUM TEACHING SYSTEM}

There are several key modules in this major. To open a door to design for students in 64 class hours, guide and stimulate students' interest, the choice of course content and the design of teaching methods are especially important. Starting from the training purpose and professional skills, based on the curriculum system of many universities at home and abroad, combined with the module teaching method and the project-based teaching method, the following teaching system has been formulated ("Table II").

12 The architectural award was initiated by Jay A. Pritzker and his wife Cindy in 1979, an architect award sponsored by the Pritzker Foundation. http://www.pritzkerprize.cn/ At present, the Pritzker Architecture Prize has gradually surpassed the "Royal British Architect Gold Award" (RIBA), Japan's "National Art Award", the Danish "Carlsberg" Award, the American Institute of Architects (AIA) "National Honor Award" and other authority awards. It has become a supreme architectural award recognized by the construction industry. 
TABle II. The Schedule of Teaching Modules of "Architectural Design Foundation"

\begin{tabular}{|c|c|c|c|c|c|c|c|}
\hline Module & \multicolumn{2}{|c|}{ No.1 } & No.2 & No.3 & No.4 & No.5 & No.6 \\
\hline \multirow[t]{2}{*}{ Weekly } & \multicolumn{2}{|c|}{ Architecture attainment } & \multirow{2}{*}{$\begin{array}{c}\text { Skills } \\
\text { Training }\end{array}$} & \multirow{2}{*}{$\begin{array}{c}\text { Space } \\
\text { limitation }\end{array}$} & \multirow{2}{*}{$\begin{array}{l}\text { Design } \\
\text { Giagram }\end{array}$} & \multirow{2}{*}{$\begin{array}{l}\text { Specification } \\
\text { for Housing } \\
\text { Mapping }\end{array}$} & \multirow[t]{2}{*}{ Practical Training Admission } \\
\hline & $\begin{array}{l}\text { Architecture } \\
\text { knowledge }\end{array}$ & $\begin{array}{c}\text { Architecture } \\
\text { award }\end{array}$ & & & & & \\
\hline No.1 & $\begin{array}{c}\text { Architecture } \\
\text { theory }\end{array}$ & $\begin{array}{c}\text { Rafael } \\
\text { Aranda \& }\end{array}$ & $\begin{array}{l}\text { Technical } \\
\text { lettering } 1\end{array}$ & \multirow[t]{2}{*}{$\begin{array}{c}\text { Ergonomic } \\
\text { s }\end{array}$} & \multirow{2}{*}{$\begin{array}{c}\text { Iconography } \\
\text { thought - } \\
\text { basic skills }\end{array}$} & \multirow{2}{*}{$\begin{array}{l}\text { Architecture } \\
\text { drawing } \\
\text { standard - } \\
\text { general rules }\end{array}$} & \multirow{2}{*}{$\begin{array}{c}\text { 《 First practical training } \\
\text { admission book 》 } \\
\text { Space unit design: student } \\
\text { dormitory actual measurement } \\
\text { and design }\end{array}$} \\
\hline No.2 & $\begin{array}{l}\text { Architecture } \\
\text { foundation } \\
\text { knowledge }\end{array}$ & Wang Shu & $\begin{array}{l}\text { Technical } \\
\text { lettering } 2\end{array}$ & & & & \\
\hline No.3 & $\begin{array}{l}\text { Skills of } \\
\text { Architecture } \\
\text { design } \\
\text { expression }\end{array}$ & $\begin{array}{c}\text { Norman } \\
\text { Foster }\end{array}$ & $\begin{array}{c}\text { Technical } \\
\text { line } 1\end{array}$ & \multirow[t]{2}{*}{$\begin{array}{l}\text { Exterior } \\
\text { space } \\
\text { design }\end{array}$} & \multirow[t]{2}{*}{$\begin{array}{l}\text { Iconography } \\
\text { thought - } \\
\text { skills } \\
\text { application }\end{array}$} & \multirow[t]{2}{*}{$\begin{array}{c}\text { Architecture } \\
\text { drawing } \\
\text { standard - } \\
\text { graphic symbol }\end{array}$} & \multirow{2}{*}{$\begin{array}{l}\text { 《Second practical training } \\
\text { admission book 》 } \\
\text { Site design: old library site } \\
\text { actual measurement and } \\
\text { transformation }\end{array}$} \\
\hline No.4 & $\begin{array}{c}\text { Formation of } \\
\text { form }(1)\end{array}$ & $\begin{array}{c}\text { Peter } \\
\text { Zumthor }\end{array}$ & $\begin{array}{c}\text { Technical } \\
\text { line } 2\end{array}$ & & & & \\
\hline No.5 & $\begin{array}{l}\text { Formation of } \\
\text { form (2) }\end{array}$ & $\begin{array}{l}\text { Kazuyo } \\
\text { Seiima } \\
\text { Ryue } \\
\text { Nishizawa }\end{array}$ & $\begin{array}{c}\text { Copy } \\
\text { drawing } \\
\text { of small } \\
\text { houses } 1\end{array}$ & \multirow[t]{3}{*}{$\begin{array}{c}\text { Architectur } \\
\text { e space } \\
\text { design }\end{array}$} & \multirow[t]{4}{*}{$\begin{array}{l}\text { Iconography } \\
\text { thought - } \\
\text { communicat } \\
\text { ion }\end{array}$} & \multirow{4}{*}{$\begin{array}{l}\text { Architecture } \\
\text { drawing } \\
\text { standard - } \\
\text { drawing } \\
\text { technique of } \\
\text { patterns }\end{array}$} & \multirow{4}{*}{$\begin{array}{c}\text { 《 Third practical training } \\
\text { admission book 》 } \\
\text { Architecture transformation: old } \\
\text { library actual measurement and } \\
\text { transformation }\end{array}$} \\
\hline No.6 & $\begin{array}{l}\text { Design } \\
\text { thoughts }\end{array}$ & $\begin{array}{l}\text { Alejandro } \\
\text { Aravena }\end{array}$ & \multirow{2}{*}{$\begin{array}{c}\text { Copy } \\
\text { drawing } \\
\text { of small } \\
\text { houses } 2\end{array}$} & & & & \\
\hline No.7 & $\begin{array}{l}\text { Design } \\
\text { method }\end{array}$ & $\begin{array}{c}\text { Balkrishna } \\
\text { Doshi }\end{array}$ & & & & & \\
\hline No.8 & \multicolumn{4}{|c|}{ Public assessment of design training works } & & & \\
\hline
\end{tabular}

${ }^{13}$ Compared with the previous course system of "Architectural Design Foundation", this system contains the expertise of the six modules. The knowledge points of each module are related to the scale, content, requirements, etc. of the training project from small space to medium space to large space. Complex upgrades and difficulty upgrades give appropriate and strong support. Each module is selfcontained, and can be partially replaced with the latest teaching and research results, and has great flexibility in teaching execution.

\section{CONCLUSION}

The teaching of "Architectural Design Foundation" should be continuously reformed and innovated in accordance with the development of the times, and continuously be improved through practice testing. After several years of teaching practice, the "Modular Project Teaching Method" is introduced in the teaching of "Architectural Design Foundation". The functional modules are flexibly configured according to the students' learning status, which brings passion and vitality to the classroom. In just 8 weeks, it effectively stimulates the enthusiasm and initiative of students, quickly cultivates and improves the overall quality of students, and optimizes the teaching effect.

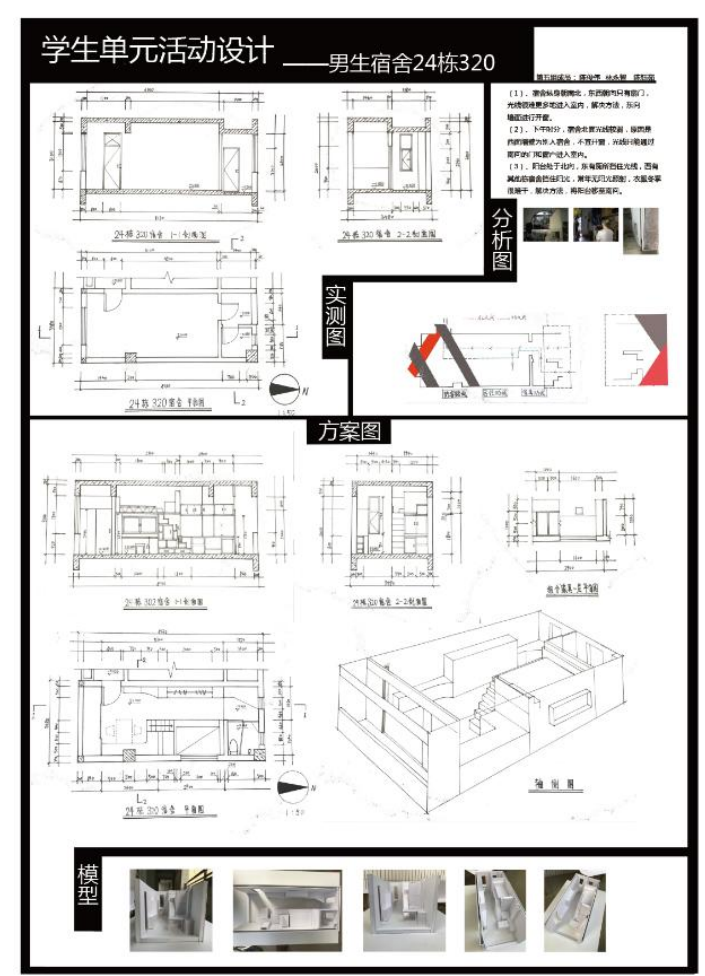

Fig. 3. One of the first training assignments.

13 In September 2015, the course plan was referred to Mr. Tian Xuezhe's "Preliminary Construction (Third Edition)" and Gu Daqing/Bai Tingwei's "Preliminary - Introduction to Architectural Design". In September 2016, the course refers to Mr. Tian Xuezhe's "Preliminary Construction (Third Edition)" and (English) Farley's "International Architecture Design Tutorial: Architectural Design Foundation (Second Edition)", (Xiao Yan/Jiang Min translation). 


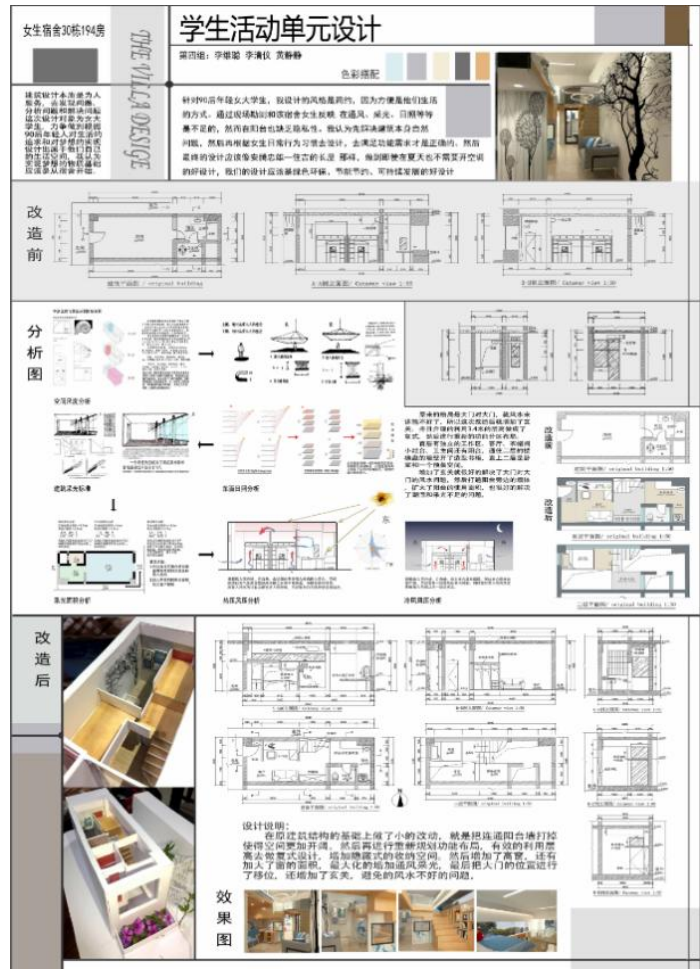

Fig. 4. One of the first training assignments.

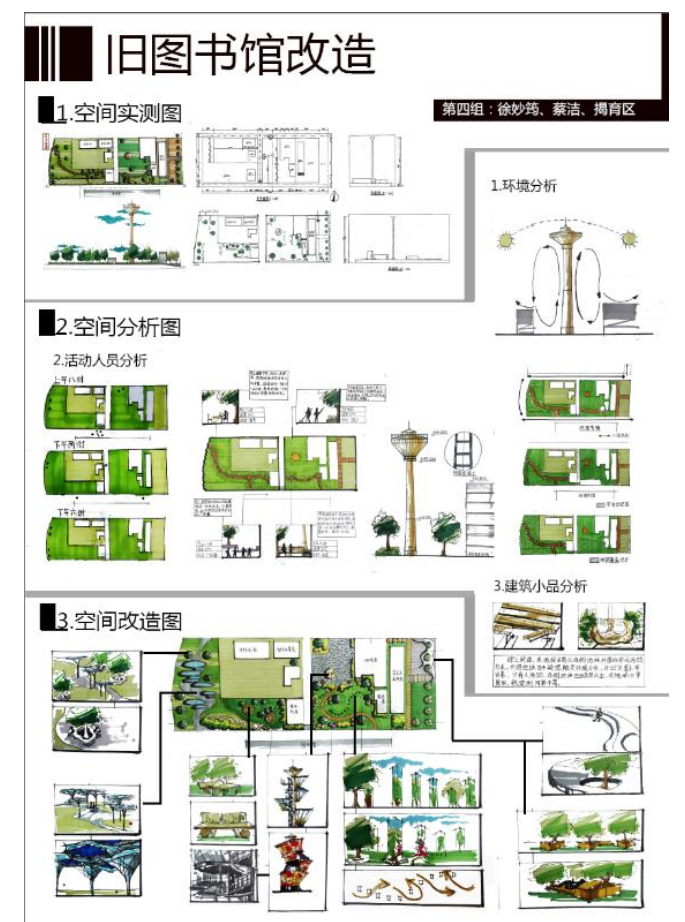

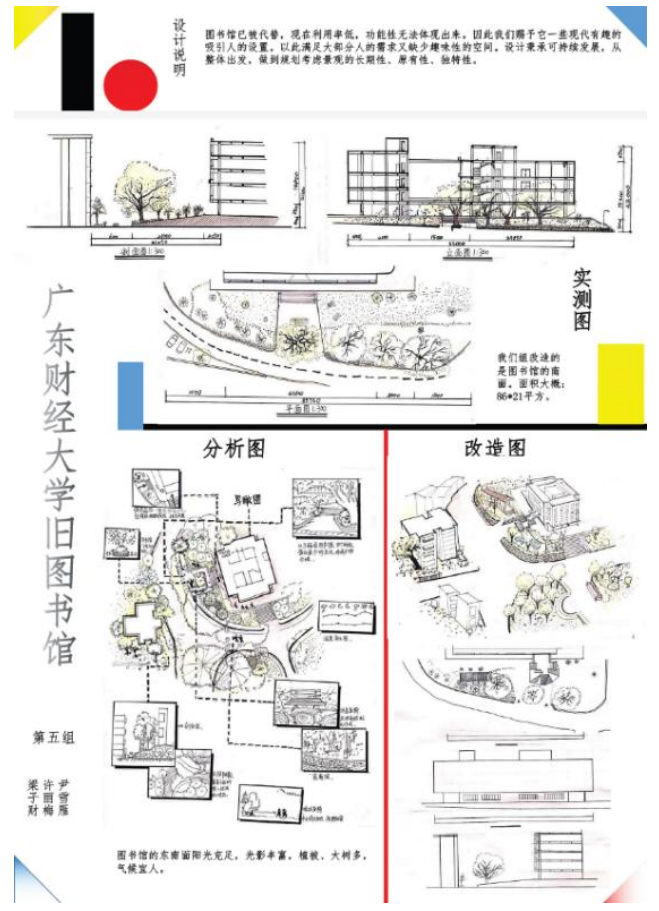

Fig. 6. One of the second training assignments.

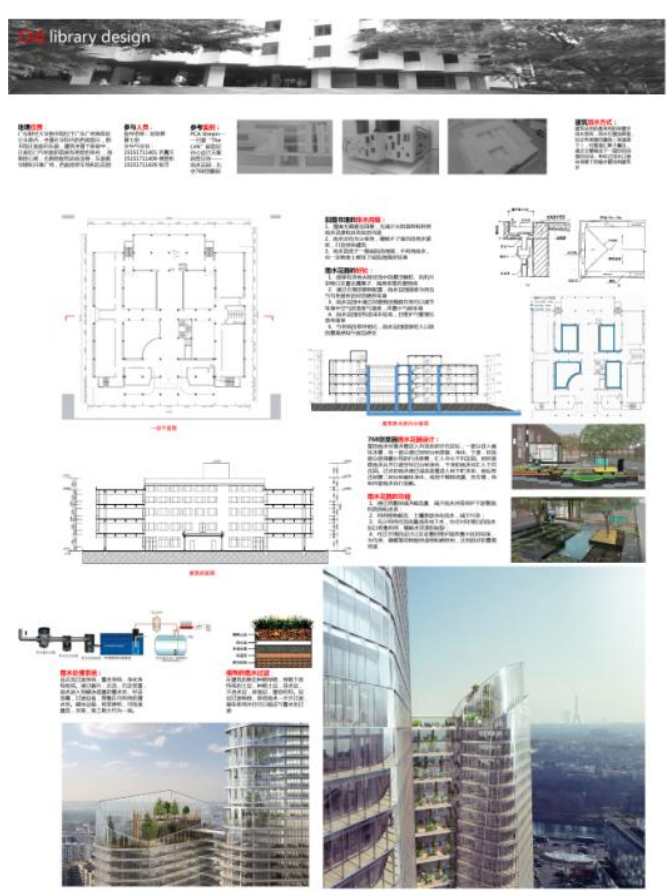

Fig. 7. One of the third training assignments.

Fig. 5. One of the second training assignments. 


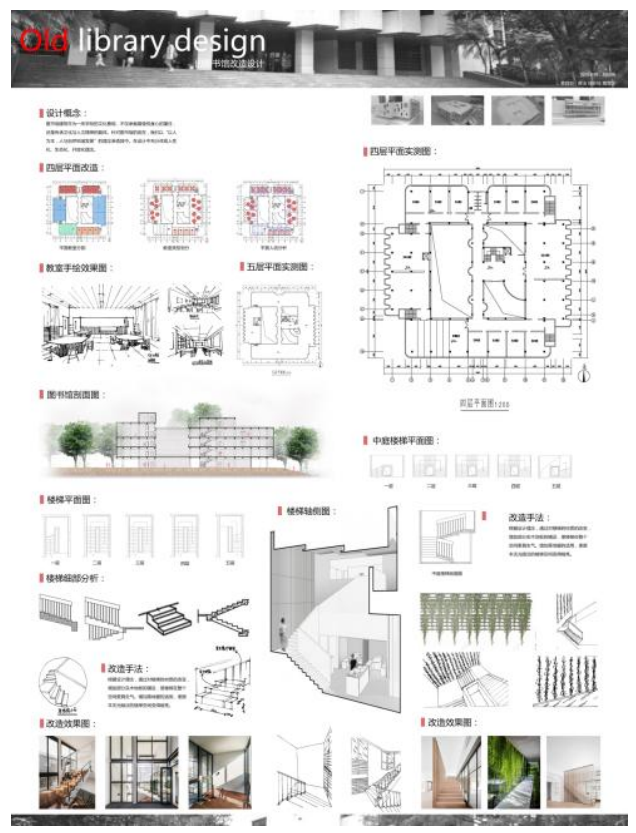

Fig. 8. One of the third training assignments.

In the future teaching practice, we continue to adhere to the interest incentives, aiming at connecting the later courses and social needs, emphasizing research and analysis, space training, group cooperation, actively promoting students' classroom discussions and self-study after class, focusing on cultivating innovative thinking, aesthetic ability, analytical thinking ability and professional comprehensive ability. We will build a teaching system of "Architectural Design Foundation" for the cultivation of high-level applied talents of environmental design major suitable for art colleges to meet the needs of regional economic and social development and the need for the construction of strong Chinese culture.

\section{REFERENCES}

[1] Zheng Jinzhou. Teaching Method Application Guide [M]. Shanghai: East China Normal University Press, 2006 (Project Teaching Method)

[2] Wang Haisong. 3+1 Student Work Exhibition of Architecture Department and the 2nd Excellent Student work Exhibition of Architecture Departmen of Shanghai University [M]. Beijing: China Building Industry Press, 2006.

[3] Wu Zhihong, Gao Lei. Order, Media and Expression. Research on the preliminary teaching of architecture combined with buzza and modern system[J]. Beijing: China Architecture Education, 2015, 03. P56.

[4] Shi Ying, Wu Guining, Pan Ying. Teaching Development and Exploration of Architectural Design Foundation [J]. Wuhan: "Huazhong Architecture", 2008 (12).

[5] Bai Xu. Discussion on the teaching reform of the initial course of architecture [J]. Chongqing: Higher Architecture Education, 2003, 03;

[6] Guo Qi. "Module" Teaching Analysis of the Initial Construction Course [J]. Building Materials and Decoration, No. 36, 2017 